\title{
A Content Analysis of Character Education Values in the English Students' Textbooks for Senior High School in Indonesia
}

\author{
Rutela Renette \\ Postgraduate Student of English Education Study Program, Bengkulu University, Indonesia \\ renetterutela2@gmail.com \\ Safnil \\ Lecturer of Postgraduate program of English Education, Bengkulu University, Indonesia \\ safnil@unib.ac.id \\ Wisma Yunita \\ Lecturer of Postgraduate Program of English Education, Bengkulu University, Indonesia \\ wismayunita@unib.ac.id \\ Corresponding Email: renetterutela2@gmail.com
}

\begin{abstract}
The aim of this research is to find out a content analysis of character values in the English students' textbooks for senior high school 10th grade, 11th grade and 12th grade and the dominant differences of character from all the books. This research employed qualitative method by using content analysis. For this research mainly character values in the textbooks was carried out. The data in this research were all passages that taken from the three English sudents' textbooks for senior high school. This research used observation check list as the instruments to evaluate coursebooks in an effective and practical way. The researcher has analyzed the data based character values found on the three books. And all of the dominants character values that the researcher were found.
\end{abstract}

Keywords: Content Analysis, Character Education, Textbook

\section{A. Introduction}

Character is needed by each one in this earth in living this life. It can be good and bad character. Someone who has good character will be good human in surrounding, in vice versa, the risky people are living in problems. Someone can be said good human when he has good moral character. According to Cohen \& Morse (2014:2) moral character can be conceptualized as an individual's disposition to think, feel, and behave in ethical versus unethical manner, or as the subset of individual differences relevant to morality. Referring to this definition, the human's character becomes main value that emphasizes among social order and the moral values should be manifested in daily life.

Becoming human with good character is one of the goals of the National Education based on the Law No.20 of 2003 on National Education System. It requires to develop the potential of learners to be faithful and pious person in only God, noble, healthy, knowledgeable, skillful, creative, independent, and democratic and responsible citizen. 
However, in fact, any moral problems were still found in society such as killing, raping, stealing, gambling, free sex, abortion, drug, even criminals were acted by the children . In this case, the government is demanded to be able to overcome critical-moral problems in Indonesia.

Considering this urgent problem, the government emphasized character education should be integrated in the field of education and put it araise into 2013 curricullum. Since character education is considered capable of overcoming any global challengesand various moral problems above. It is in line with Panthachack (2012) stated that character education becomes a priority in achieving the children' academic needs regarding to ethical, social, and beliefs of emotional development of the children. Encouraging and promoting caharacter education as a part of the mission becomes the schools' duty (Schaeffer,1999 as cited in Lewis \& Ponzio, 2016), and giving the character values and making students to gain these values through experiences at school (Otten, 2000). In addition, character education brings long-term moral, ethical and academic solution to issues that cause interest in school and society life, and teaches children how they can be the best and how to do any things as well (Character Education Patnership, 2017). It means that the educational institutions have a big role together with other stakeholders and school members in the embed of character values towards students' learning process. They should take one action to reach out the goals of education.

Besides, the role of teachers as a model following the parents is very crucial to influence students' character. It is because the students spent particular time to achieve such education. They are then having the desire to do what is right and manifesting what they have learn from school to their real life as citizens. Here, the role of parents, of course, quite needed to help children understand in the embed of the character values and become good humans. As Campbell (2003) stated that education promotes the intellectual, social, emotional, and ethical development of young people and share a commitment to help them become responsible citizens. That is why the character education should be embedded in early age not only in schools but also in family and in society.

To help the learners are able to reach out the goals of education, several components should be pointed out such as curriculum used, syllabus, materials given by the teachers, etc. One of the important aspects is textbook itself. As List (2005) \& Martina, et al. (2020) stated that textbook serves as the primary source of learning, complementary materials, inspiration and class activities and the curriculum itself. It means that textbook becomes a tool for the 
teachers and the learnes in gaining them to understand what the textbook provides inside. In other word, textbook can help teachers and students in understanding the materials in teaching learning process. Besides, textbook should engage students to foster character values based on the goals of the National Education, namely: religiosity, honesty, tolerance, discipline, hard-working, creativity, independence, democratic, curiosity, fondness of reading, responsibility, nasionalistic, patriotic, rewarding achievement, friendly/communicative, love of peace,environmental caring, and socialable (Kemendiknas RI, 2011).

By seeing the character education integrated in 2013 curriculum, it has been the teachers' duty to sellect and find the best textbooks in teaching in the classroom. What textbooks should be provided, what materials should be given in which approriate to the students' needs. And the most important thing is what contents would be served to the students in order they can get not only academical achievement but also character values. So, it is important to analyze the contents from the textbooks used by the schools and the teachers.

From the explanation above, the researcher tries toconducta content analysis of character education values in the English students' textbooks for Senior High School in Indonesia.

\section{B. Research Methodology}

\section{Research Design}

This research is qualitative by using content analysis.Since this research will be presented in descriptive form, it can use qualitative or quantitative method to describe or interpret a current event, condition, or situation and the current topics (Picciano, 2018:1). According to Krippendorf (2013:18) content analysis as a research technique for making replicable and valid infrences from the texts (or other meaningful matter) to the contexts of their use. As a research technique, content analysis provides new insights and increases a researcher's understanding of particular phenomena. This research aims at analyzing or describing the data: 1) what characters are found, and 2) whether or not the differences dominant character values in books. At the end, the description of the data will present in descriptive form including numeration as well.

\section{Data and Source of Data}


The data of this research is all passages taken from the three of English students' textbooks for Senior High School. While, the sources of the data are English students' textbooks entitled Bahasa Inggris for SMA/MA grade X. It is authorized by Utami Wid Zuliati Rohmah, and Furaidah and published in 2017 revised edition.The second one is Bahasa Inggris for SMA/MA Grade XI which is authorized by Emi Emilia and Helen. I. R. Agustien and published in 2017 revised edition. The third textbook is Bahasa Inggris for SMA/MA grade XII which is authorized by Utami Widiati, Zuliati Rohmah and Furaidah and published in 2018 revised edition. These textbooks are selected to find out whether character education characteristics appears or not in the textbooks and how good those textbooks for Senior High School students.

\section{Instrument of the Research}

This research uses observation checklist as the instrument. Checklist is an instrument thathelps practitioners evaluate coursebooks in an effective and practical way.

\section{Data Collection}

In collecting data, the researcher systematically explain about the ways of selecting data with the relevant criteria between data and the focus of the research. It involves what theresearcher can do with and by sorting and coding the data that are necessary to analyze. According to Ary et al. (2010:458) the steps of the data collection method in content analysis can be described as follows:

1. Specifying phenomena to be investigated. Here, the character education is specified to analyze.

2. Selecting media to observe. In this case, there are three of English students' textbooks for Senior High School that the researcher has mentioned above.

3. Formulating exhaustive and mutually coding categories. The eighteen of character values become the focus of the coding in counting in this research.

4. Deciding on the sampling plan to use. It aims at obtaining a representative sample of the documents. Here, the researcher carries out 2013 curriculum as the main emphasis of character education.

5. Training the coders. The researcher will do coding the documents using the scheme and obtain consistent result. If the reliability of inter-rater is qualified, so it will continue to the next step. When it is not reliable, it might be corrected again to get the best interpretation. 
6. Analyzing the data. To anlyze the data should be involving the frequency of characters occurance in each material and the percentage with different categories or choosing different other descriptive numerations.

\section{Data Analysis Procedure}

After collecting the data from the textbook as a document in this research, the data were analyzed qualitatively. In analyzing the data, the researcher uses content analysis as a technique. The data are then taken from the data source and it could be well understood by the readers as a findings interpretation. As Bungin (2008:159) stated that content analysis technically includes the efforts, classify the symbols used in communication, use some criteria in classification, and use particular technique in making prediction. Here, the researcher will analyze the data based on Ary et al. (2010:481-490) about analysis procedures. The stages are:

1. Organizing and Familiarizing

In this step, the researcher organizes the data chapter by chapter become familiar with the data and put them into a form to analyze, the researcher then cluster the same character values in every figure as familiarizing step.

2. Coding and Reducting

After familiarizing and organizing the data to be easily retrieved, the researcher begins to do coding and reducing process. Here, the researcher needs to code and reduce based on the character education lists and can limit as objective of the research.

3. Interpreting and Presenting

Interpreting involves reflecting the words, acts and gives the meaningful understanding. In this step, the researcher will bring out the meaning, telling the story, providing an explanation, and developing plausible explanations and present the description related to the data.

From the theory above Ary et. al (2010:481-490), moreover, to state the research findings as

\section{Results and Discussion}

\section{Results}

\section{Character Values Appeared in Three Textbooks for Senior High School in} Indonesia.

a) Character Education Values Found in Book 1 
There are 13 texts of book 1 . The analyzed data of the character values are presented in the following graphic.

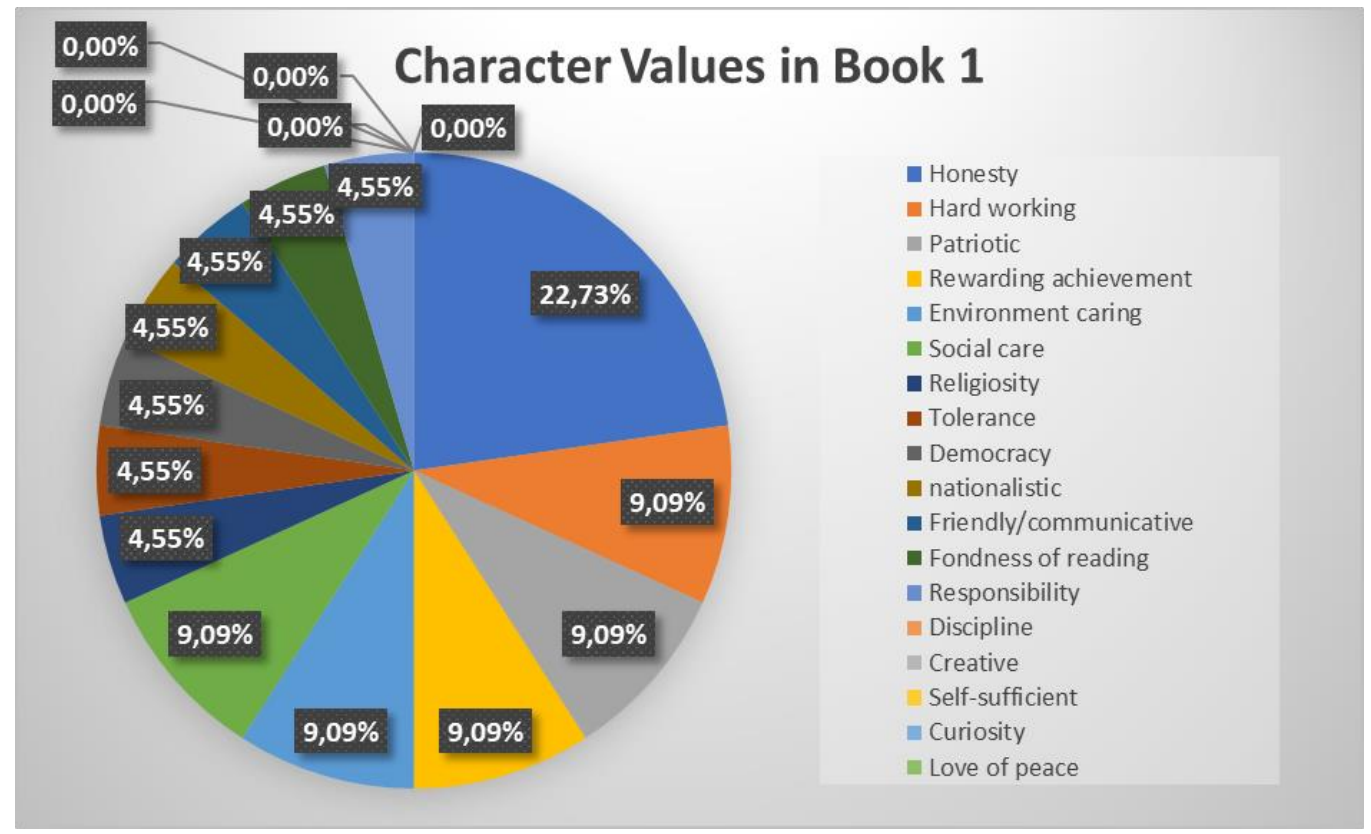

Graphic 1. Character Values in Book 1

Based on the graphic 1 above, it can be seen that the dominant character values in book 1 is honesty. The percentage is $22,73 \%$. The second dominant characters are hard working, patriotic, rewarding achievement, environment caring, dan social care, which appeared in $9,09 \%$. And then there are several character values that didn't appear at all in the book 1, such as discipline, creative, self-sufficient, curiosity, and love of peace. 


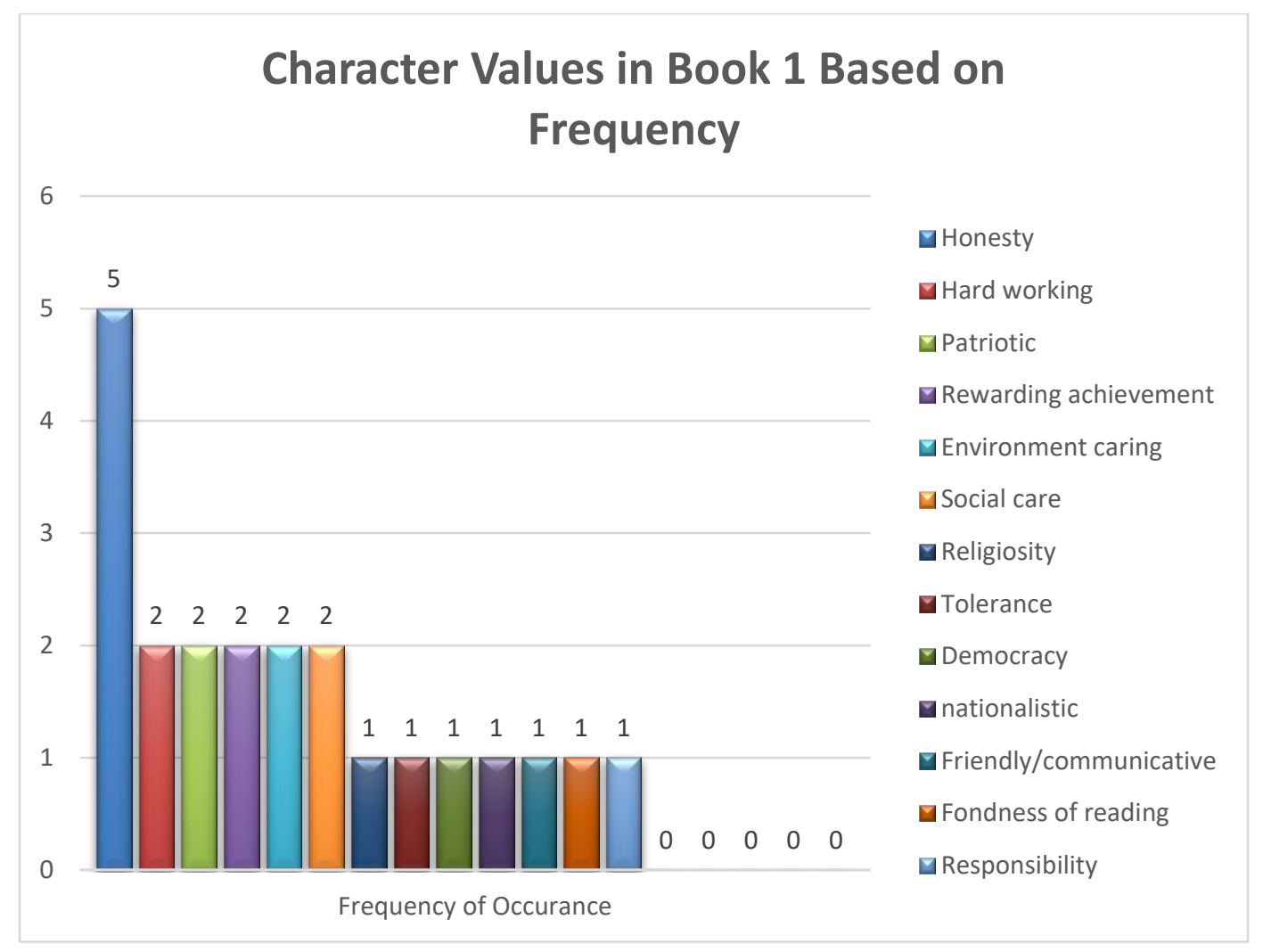

Graphic 2. Character Values in Book 1 Based on Frequency

From the graphic 2 above, it can be seen that appeared five times in the passages, so it becomes the most dominant in the book 1. While the second dominant characters are hard working, patriotic, rewarding achievement, environment caring, and social care. Each of them appeared twice.

\section{b) Character Values Found in Book 2}

In the book 2, there are 19 reading passages gained by the researcher. The character values found in book 2 can be seen in the the graphic below. 


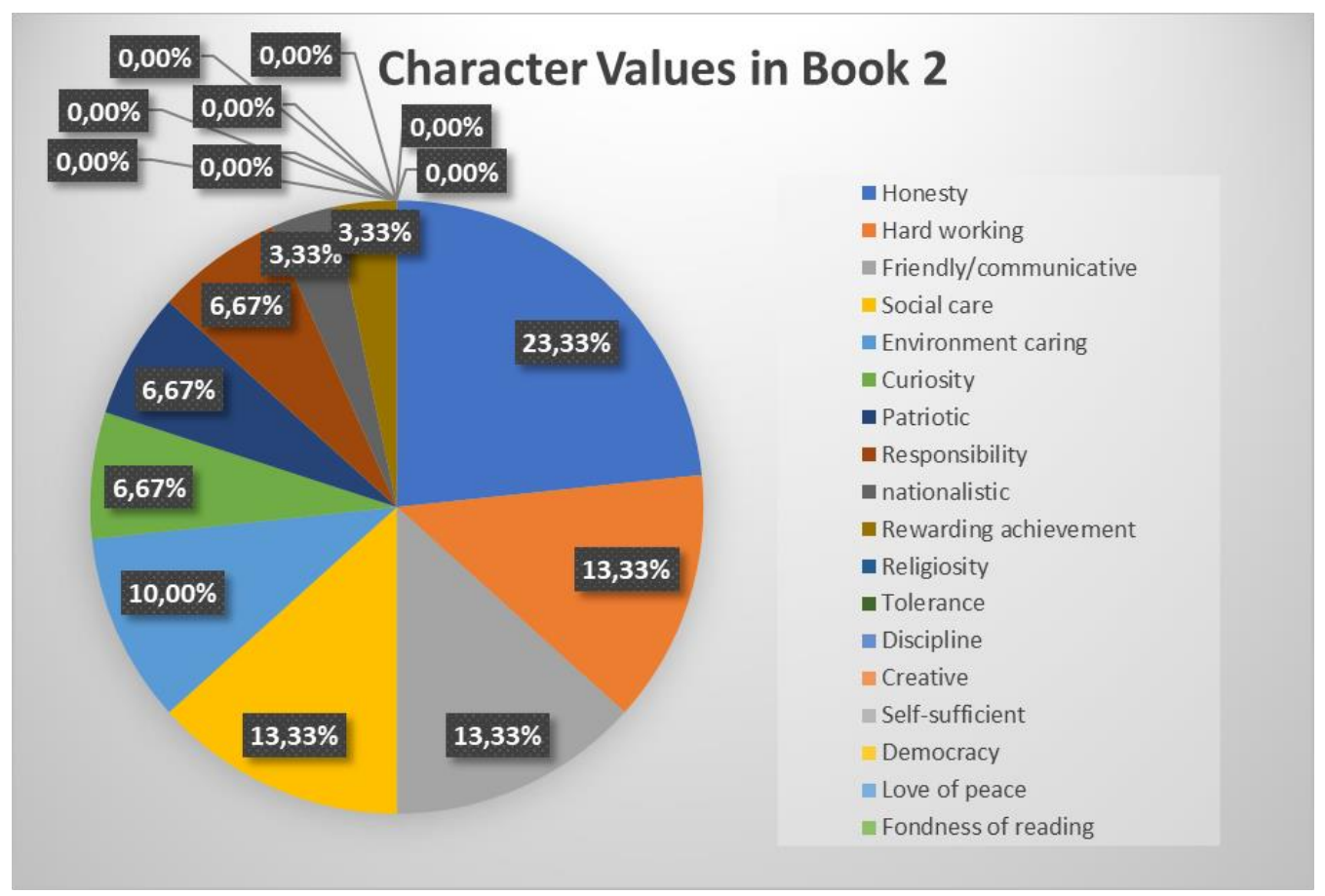

Graphic 3.Character Values in Book 2

Based on the graphic 3 above, it can be seen that the dominant character values in the book 2 is also honesty that appeared in $22,73 \%$. While the second dominant characters are hard working, friendly/communicative, and social care which appeared in 13,33\%. The characters that didn't appear in the Book 2 are religiosity, tolerance, discipline, creative, self-sufficient, democracy, love of peace, and fondness of reading.

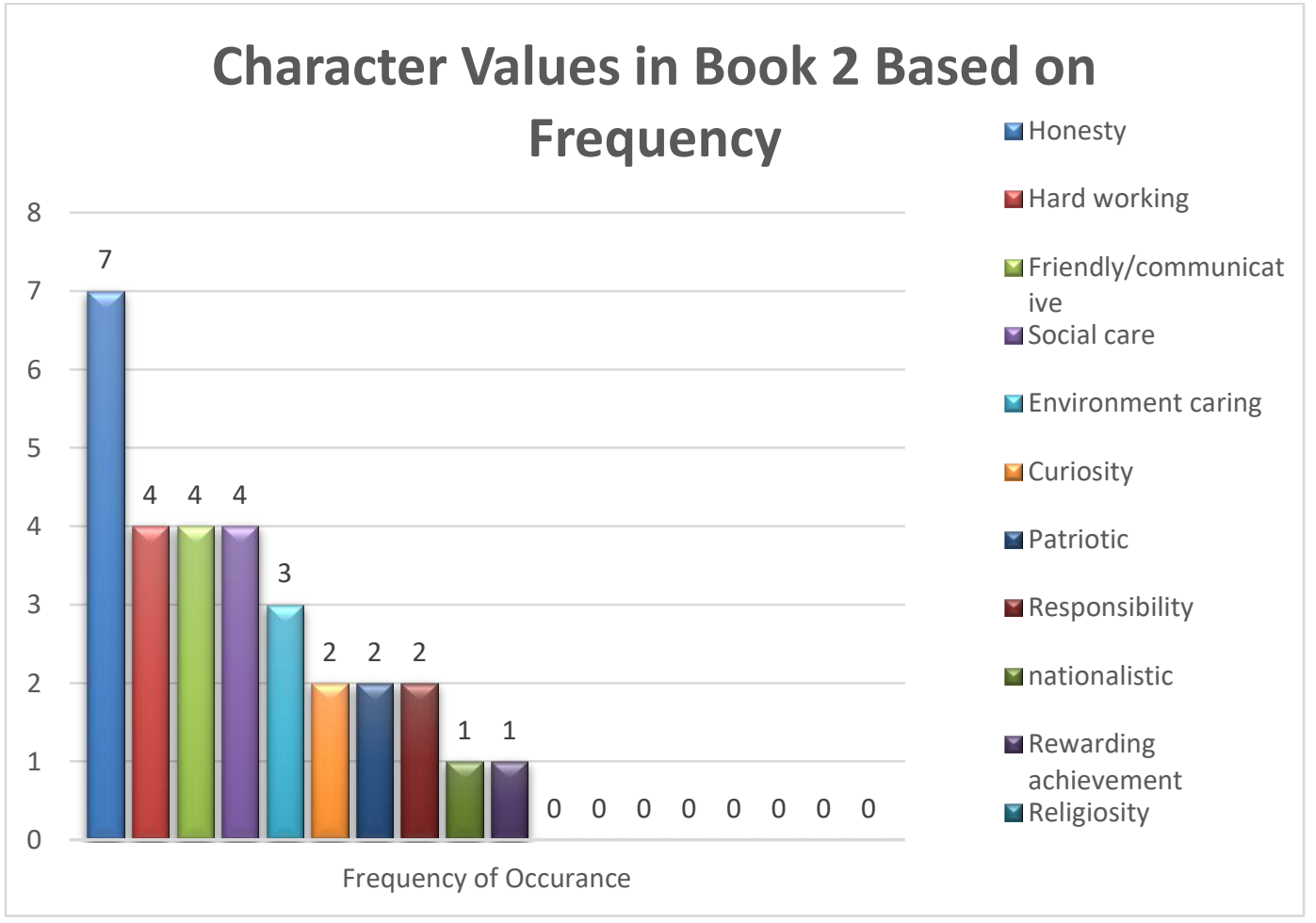




\section{Graphic 4. Character Values in Book 2 Based on Frequency}

From the Graphic 4 above, it can be seen that the value of honesty appeared seven times, so that honesty becomes the dominant character in the book 2 . While thesecond dominant character values are hard working, friendly/communicative, and social care that appeared four time in all passages.

\section{c) Character Values Found in Book 3}

There are 15 texts taken from the book 3. The character values found are presented in graphic 5 .

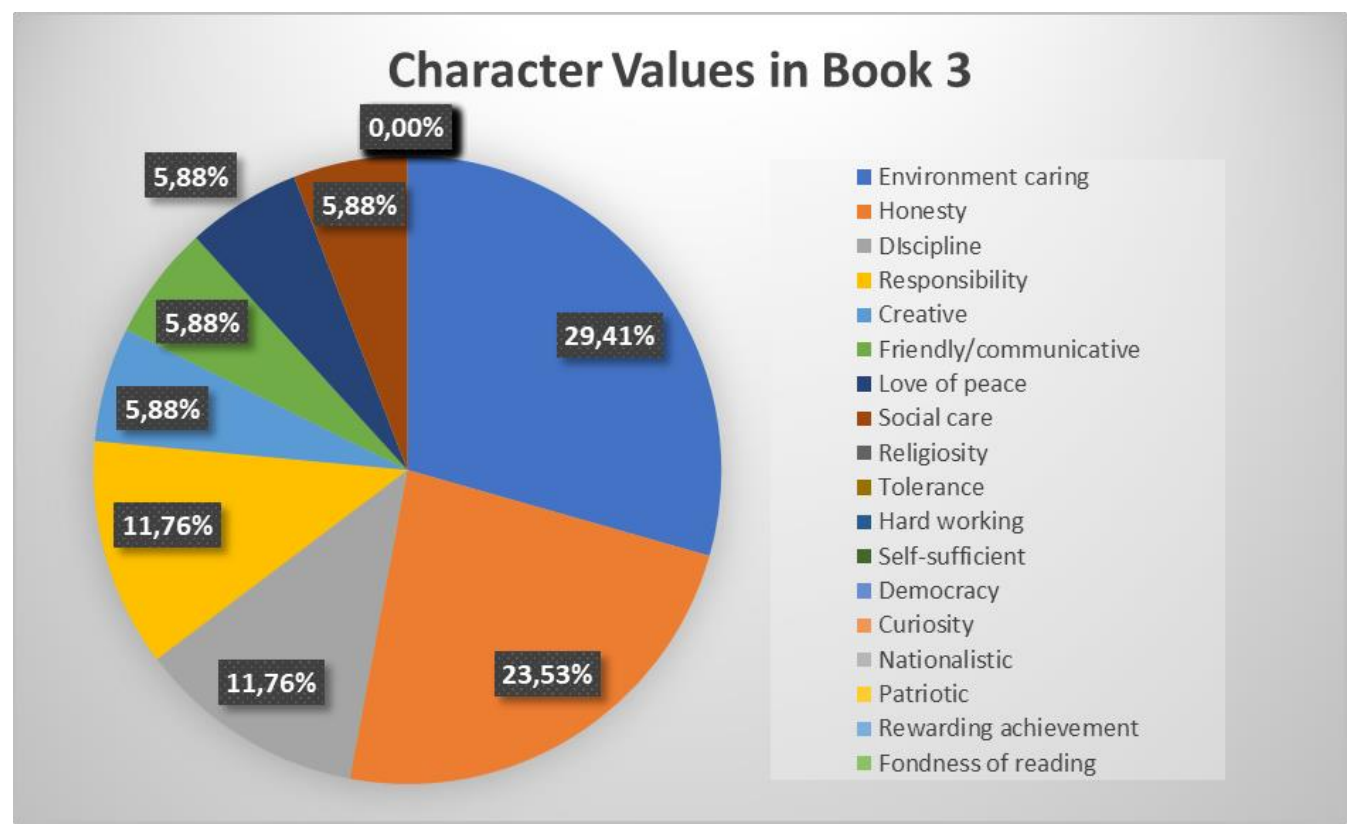

Graphic 5. Character Values in Book 3

Based on the Graphic 5, it can be seen that the most dominant caharacter value in the book 3 is that appeared in $29,41 \%$. While the second dominant character value is honesty that appeared $23,53 \%$. The third dominant character appeared in $11,76 \%$ si discipline. Also, some values which didn't appeared at all in the passages in the book 3 are religiosity, tolerance, hard working, self-sufficient, democracy, curiosity, nationalistic, patriotic, rewarding achievement, and fondness of reading. 


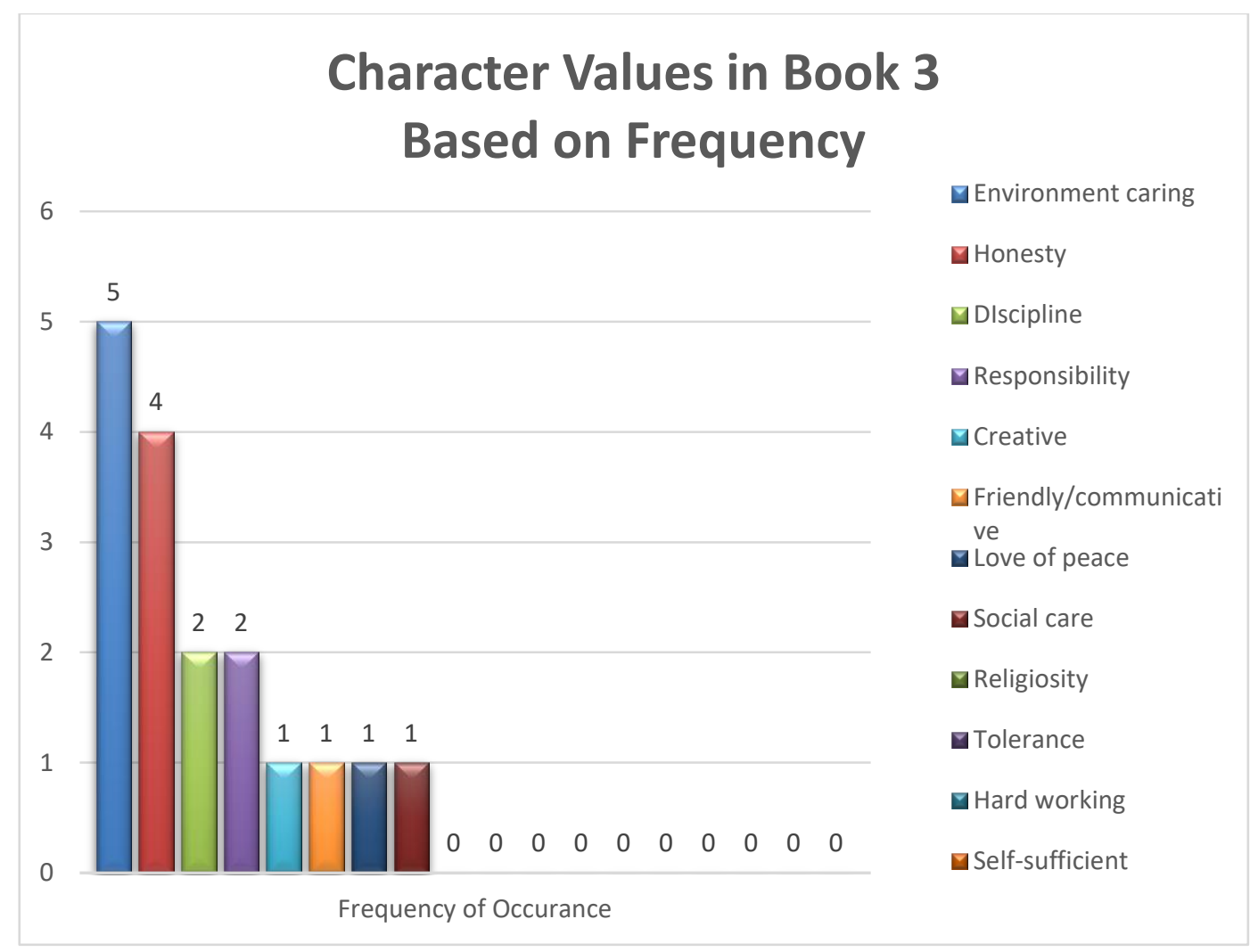

From the Graphic 6 above, it can be seen that the value of environment caring appeared five times and becomes the most dominant character in the book 3 . While honesty appered four times and becomes the second one and the third dominant character is discipline that appeared twice.

\section{Discussion}

The first research question is what character values are found in the English students' textbook for Senior High School in Indonesia book 1. From the 18 character values that are existed, the findings out of the texts only thirteen values appeared in the books, while another does not. It means that the values are not balanced. One value can be mostly appeared, while the others are nothing. To answer the reason why some values were not appeared, this probably caused by the difficulty of finding the text that relies on the values such as discipline, creative, self-sufficient, curriosity, and peace of love.

The second research question is related to what character values are found in the English students' textbook for Senior High School in Indonesia book 2. The results show that the character values are also not balanced. One can be mostly appeared and another is nothing. From the 18 character values that are existed, only ten values appeared in the passages of the book. This probably caused by the difficulty of finding the text that relies on 
the values such as religiosity, tolerance, discipline, creative, self-sufficient, democracy, love of peace, and fondness of reading. It means that view character values in the textbooks cannot be developed in the classroom.

The third research question is what character values are found in the English students' textbook for Senior High School in Indonesia book 3. The results show that from the 18 character values that are existed, only eight values appeared in the passages of the book. It means that the higher level the less character values in the book developed. Those findings are in line with Koesoma (2009), Abidin (2012), Cohen \& Morse (2015) and Zurqoni, et al. (2018) who stated that three are several values of character in textbook, such as religiosity, tolerance, discipline, creative, self-sufficient, democracy, love of peace.

\section{Conclusion}

From the results, it can be concluded as follows:

1. Based on the analysis data of book 1 from the Ministry of Cultural and National Education for first grade Senior High School found that he most dominant character value in book 1 is honesty among all of the character values.

2. Based on the analysis data of book 2 from the Ministry of Cultural and National Education for second grade Senior High School found that the most dominant character value in book 2 is honesty among all of the character values.

3. Based on the analysis data of book 3 from the Ministry of Cultural and National Education for third grade Senior High School found that the most dominant character value in book 3 is environment among all of the character values.

\section{References}

Abidin, Y. (2012). Pembelajaran Mambaca Berbasis Pendidikan Karakter. Bandung: PT. Refika Aditama.

Ary, D., Jacobs, L. C., Sorensen, C., \& Razavieh, A. (2010). Introduction to Research in Education $8^{\text {th }}$ Edition. USA: Wadsworth.

Bungin, B. (2008). Metode Penelitian Kualitatif. Jakarta: Kencana.

Character Education Partnership. (2017). 11 principles of Effective Character Education. Retriewed from http://www.character.org/uploads/PDFs/Misc/FAQs.pdf

Cohen, L. Et al. (2007). Research Methods in Education $6^{\text {th }}$ Edition. New York: Routledge.

Cohen, T. R., \& Morse, L. (2014). Moral Character: What it is and what it does. Retrieved fromhttps://www.researchgate.net/publication/264000952.

Elkind, D. H. \& Sweet, F. (2004).How to do character education. Retrieved from http://www.goodcharacter.com/article4.html.

S. (2005). Teaching ESL composition. London: Lawrence Erlbeum Accociates. 
Kemendikbud RI. (2011). Pendidikan Karakter untuk Membangun Karakter Bangsa. Jakarta: Direktorat Jendral Pendidikan Dasar.

Kemendiknas RI (2011). Pengembangan pendidikan budaya dan karakter bangsa. Jakarta: Badan Penelitian dan Pengembangan Pusat Kurikulum dan Perbukuan Kemendiknas. [Kemendiknas RI. (2011). The development of nation cultural and character education. Jakarta: Badan Penelitian dan Pengembangan Pusat Kurikulum dan Perbukuan Kemendiknas.]

Koesoema, D. (2009). Pendidikan Karakter di Zaman Keblinger. Jakarta: Grasindo

Krippendorf, K. (2013). Content Analysis an Introduction to its Methodology Second Edition. London: Sage Publications.

Lee, A. (2016). Implementing character education program through music and integrated activities in early childhood setting in Taiwan. International Journal of Music Education 34(3), 340-351.

Martina, F., Syafryadin, S., Rakhmanina, L., \& Della, T. S. (2020, November). An Analysis of Textbook for Banking Department Students Entitled English for Banking and Finance by Rosemary Richey. In International Conference on the Teaching English and Literature (Vol. 1, No. 1, pp. 287-295).

Otten, E.H. (2000).Character education, ERIC Clearinghouse for Social Studies/Social Science Education. ERIC identifier: ED444932. Retrieved from http://www.hiho.ne.jp/taku77/refer/444932.htm.

Panthachack, L. (2012). Character education a qualitative review analysis an relevancence of educational leader's perceptions and experiences with character development (Master thesis). Graduate Faculty of Frenso Pacific.

Picciano, Anthony. (2018). Descriptive Research. Available at https://www.anthonypicciano.com/education-research-method.

Republik Indonesia. (2003) Undang-undang no 20 tahun 2003 tentang sistem pendidikan nasional. [Republic Indonesia. (2003). Law number 20 year 2003about the national education system.]. (Idn).

Schaeffer, E. (1999). It's time for schools to implement character education. NASSP Bulettin. $83,1-7$.

Zurqoni, Retnawati, H., Arlinwibowo, J., \& Apino, E. (2018). Strategy and implementation of character education in senior high schools and vocational high schools. Journal of Social Studies Education Research 9(3), 370-397 